\title{
Josie Arnold
}

\section{Meeting the Platypus: When fact equals fiction}

\section{Coming to know: the idea of mystory/mystery}

This paper works within an early model postulated by Gregory Ulmer (1989). In his development of an idea that there is in academic writing the self and the researched, the conscious intellectual semiotic and that arising from storytelling, Ulmer surveys the idea of 'mystories'. A 'mystory' puts under erasure all claims to fact in writing. It shows all writing to be both personal and mysterious (my story and mystery) whatever its claims to authenticity and depersonalisation. In this sense, everything is a fictional narrative:

To approach knowledge from the side of not knowing what is, from the side of one who is learning, not that of one who already knows, is to do a mystory. What is the experience of knowing, of coming to or arriving at an understanding, characterized as following a path or criss-crossing a field, if not a narrative experience, the experience of following a narrative? (Ulmer 1989: 106)

This produces a postmodernist pastiche that is self-reflexive, and reveals itself as a work in progress. Such a pastiche is not easily recognized by readers looking for and/or comfortable within traditional forms of academic discourse. It sees language as frail and yet paradoxically producing what Gilles Deleuze calls 'sense' (May 2006: 39). Yet, as Cleo Cherryholmes has said, knowledge is constrained by these past expectations: '... our legacy of positivism continues to reinforce acontextual and ahistorical scientific narratives of construct validation, hypothesis testing and programme evaluation' (Cherryholmes 1988: 441).

The 'mystory', on the other hand, acts to reveal how all discourse, perhaps especially that claiming to be disinterested and objective, is of a rather more discursive and even fictive status so that '... no rigorous definition of anything is ultimately possible' (Spivak 1988: 77). Representations of knowledge are shown to be personal, tentative and made up of a tissue of sourced quotations. In admitting the text to be non-seamless, a number of resonances occur. Among them are: the empowerment of the reader over the authority of the author; indications of the readerly possibilities of the text rather than the confining claims of a linear finishing argument; the use of a toolbox of quotations rather than an analysis of the literature in a traditional literature review; and found or imagined material that produces 'mystory'. 
Ulmer calls this a 'popcycle' as it brings together expert knowledge, explanatory knowledge and everyday discourse, experiences and common sense. The mystory provides us with a textual practice that is also a recognition that there is no objectivity, no apparent non-situated universal standpoint so that knowledge is shown as 'a context-specific kind of story-telling' (Lyotard 1988: 76).

In many ways, Ulmer's original 'mystory' enacts sympathetically with my ideas of feminist poetics. It certainly accords with Mary Midgley's views on lifeshaping myths and their relationship to knowledge, even scientific 'truths'. She sees them as:

imaginative patterns that we all take for granted - ongoing dramas inside which we live our lives. These patterns shape the mental maps that we refer to when we want to place something. Such ideas are not just a distraction from real thought, as positivists have suggested. Nor are they a disease. They are the matrix of thought, the background that shapes our mental habits. They decide what we think important and what we ignore. They provide the tools with which we organise the mass of incoming drama. (Midgley 2006: 4)

'In mystory, the research is motivated by a search for one's wide image, for the emotional atmosphere that mediates one's own knowledge and expertise' (Ulmer \& Memmott 2000: 3). Through the fictional truth of constructed narratives, which is most clearly able to be seen in the novel, we are given opportunities to enjoy our imaginative inner life more comprehensively. The novel encourages our own creative understandings and insights through the construction of a real/unreal world peopled by real/unreal characters speaking real/unreal dialogue. It does not come from the position of the authoritative in the same way as the work of theoreticians and semioticians, or indeed any other 'gatekeepers'.

The semiotician, Goren Sonesson, for example, sees narratives as implying a structure, a kind of 'fictional truth' in which both writer and reader experience ideas, issues, life itself in a non-threatening fictional world that allows for imaginative construction of self. What - if any - semiotics enables us to understand this narrative? Sonesson says that 'all we need are schemes' (Sonesson 1988: 15) because schemes enable the perceiver to modify through experience what is perceived so as to understand, explore and adapt the intake of information. They do so by placing perception and understanding within a setting, framework or cultural construction. Sonesson describes schemes as the 'lattice pegs on which individual facts may be hooked up' (Sonesson 1988: 16). These 'lattice pegs' rely upon a kind of shared cultural knowledge that is in itself quite authoritative and dependent upon a closed and enclosed space.

On the other hand, Julia Kristeva calls the novel an open psychic space and states:

I speak in favor of imagination ... [n]ot in favor of 'power of the imagination', which is the rallying cry of perverts longing for the law. But in favor of saturating powers and counterpowers with imaginary constructions-phantasmatic, daring, violent, critical, demanding, shy. ... Let them speak ... Imagination succeeds where the narcissist becomes hollowed out and the paranoid fails. (Kristeva 1987: 381) 
Such a resurrection from the dead is audacious: in not 'longing for the law', we can develop insights into how creative writing pushes the boundaries and paradigms of the 'givens' of society and culture. This leads us also, in practice as well as in theory, to understand and interrogate fruitfully the relationships between reading and writing. The publication to a broad audience of creative writing such as short stories and novels is relatively recent. There was an upsurge in such publishing in the nineteenth century. This has been slightly diminished since the spread of cinema, television and computers as modes of delivering 'mediated experiences' quickly, easily, cheaply and in an entertaining fashion. Yet reading creative works is still the basis of a huge industry and the book in print continues to dominate creative expression for many.

\section{The audacious narrative: the subversive potential of creative writing}

Roland Barthes' once revolutionary idea that authority can be displaced is enacted in the constructed fictional truth of the novel. The novel is perhaps the best model of the 'mediated experience' of print stories for a wide public dissemination. Originally, it was seen by many as decadent and a way in which female minds were threatened by excitements beyond what they could properly maintain. For example, Dr Kellogg's concern for human health led to the invention of cornflakes for a healthy breakfast. He also identified the reading of novels as overly exciting and hence: '...one of the greatest causes of uterine disease in young women' (in Spender 1991: 9).

Once upon a time, as well as the reading of literature being castigated as dangerous to women's health through over-excitement, the study of literature was seen as an oxymoron. Literature was not there to be studied. It was a place in which stories were told, characters were invented and met and plots were unveiled. At its highest in poetry, literature informed the mind by putting the right word in the right place. It helped to pass the time. In many ways, it was a dangerous place. Inevitably it involved the emotions and just as inevitably this led to anarchical responses rather than quantifiable and scientific truths (Arnold 1994).

By understanding and interrogating fruitfully the relationships between reading and writing, we can develop insights into how creative writing pushes the boundaries and paradigms of the givens of society and culture. If the written discourse is not intransigent, but open - or indeed subject - to individual readings, then it is quite uncontrollable. Clearly, the imaginary is in its own way quite dangerous: it lifts us from our 'real' lives and provides us with windows on to other worlds and with doors through which we can move to question and interrogate our own lives. We can see this in the fact that much published creative writing has fallen foul of the authorities. It can be treated as 'censored' and withdrawn from publication (even burned), because it is deemed unsuitable.

In a democracy, direct censorship is an interesting issue that highlights the acceptable ways in which the imaginary can be placed in the community. Much censorship today is to prevent unacceptable sexual or violent images from being a 'mediated experience'. Political censorship means that creative materials are banned because they oppose the ideology of the state.

Censorship of creative works shows the extent to which they are regarded as being influential in and on the society. Creativity itself may be seen as a radical aspect of culture rather than a conforming one. If we all did exactly what was expected and allowed, then clearly creativity could not flourish. Fictional truth 
acts to encourage our own creative understandings and insights. There are synergies between the 'imaginary' and the 'real'; we share the imaginary with others who read or write creatively, and apply insights developed through creative writing to our lives.

\section{The mystory: personal and tentative}

As we come to be at ease with creative writing/reading, we also understand the strength of words in conveying shared meanings while at the same time - and quite paradoxically - reflecting upon the frailty of words in conveying shared meanings. Julia Kristeva has moved from being a theorist in semiotics, love, abjection and intertextuality, to being a novelist. She claims that she has always interjected her personal self into her essays, never hiding behind academic cultural practices. But what has she to say about the difference between the two writings under her pen? In writing about love in her theoretical mode, she has called love 'incommunicable', asking: 'Are not two loves essentially individual, hence incommunicable, and thus don't they condemn the parties to meet only at a point infinitely remote?' (Kristeva 1987: 3). Perhaps she found that for her, love was incommunicable any other way than as a fictional truth.

The word 'incommunicable' interests me here. It suggests that it is impossible to convey love because there are no words to take the individual from self to other. In her theoretical writing, Kristeva calls this a 'vertigo of identity'. Of writing fiction, she says that for her:

writing novels is a sort of process I like to call transubstantiation. There is, as I see it, a very strong linkage between words and flesh in writing fiction. It's not merely a mental activity. The whole personality is in it. You have psychology, you have belief, you have love affairs, you have sexuality, you also have a connection to language. When I'm writing novels, I am making a voyage around, or into, myself. I do it also, of course, in my essays. But my essays are a defence of my self-voyaging. In the novel, I take all the risks of the traveller, or the explorer. And I get the pleasures as well. (quoted in Sutherland 2006: 13)

Is Kristeva's narrative self-journey, then, somehow more 'creative' than her theoretical writings? She describes them as 'a defence of my self-voyaging'. She herself draws a line between the two genres of writing. It seems as though the 'creative' writing is more risky to the self: it is an explorative task that is somehow more of a journey into the unknown. This indicates that narrative fiction has a very powerful creativity in itself. Does this necessarily indicate that such power should be confined to fictional writing?

\section{Umberto Eco introduces Kant to the platypus: the 'mystory' as both fact and fiction}

The relationship of fact and fiction (of the serious and the somehow entertaining) can be seen where theorists talk about writing and also practise it. Umberto Eco works the paradox that might be seen between the theory and the practice of writing. His work as a Professor of Semiotics at the University of Bologna has been overshadowed by his success as the author of best-selling fiction in which he explores his theoretical understandings. Central to his 'creative fiction' is building credible narratives and characters that explicate his 
theories of semiotics and aesthetics by playful use of symbolism, allusions and cross-references, humour and irony, his puzzles and his narrative inventions.

Eco is interested in the ways in which we come to understand things, in particular, the meeting of our cognitive perceptions with our language descriptions and interpretations (Eco 1997). His title Kant and the Platypus is very suggestive of this. He states that for Kant: '... information provided by the senses was insufficient, because you need the intellect that reflects on what senses have put before it' (Eco 1997: 76). This indicates to me the power of the Cartesian separation of intellect and feeling as a strong influence on the Eurocentred thinking that underpins historical and neocolonialism. Indeed, to me, this is an outstanding example of the colonisation of First Nation knowledge and experience, words and understandings, by definitions that accord with the dominant Western mode of thinking.

There is no more mysterious creature to the European than the Australian platypus. Its discovery by white settlers is in itself instructive of the puzzle that Eco indicates in his title. Of course the platypus was well known to the Indigenous inhabitants. In an unselfconscious display of Indigenous pragmatism and acceptance, they made splendid cloaks from its waterproof fur, and ate both its flesh and its eggs. There was, however, no animal like it in European knowledge. It was first recorded by Europeans on the banks of a lake near the Hawksbury River in New South Wales in 1797. They called it a 'water mole' because it seemed to live under water. While Eco questions what Kant would have done if he had ever come across the platypus, he cannot respond to his own question without moving from Kant to Peircean semiotics, which deny 'that intuition produces any power and asserts that all cognition springs from previous cognitions'. These bring 'into play an inferential process that, no matter how instantaneous and unconscious, verifies the sensation's reliability' (Eco 1997: 112). The platypus did not exist for Europeans because they had no previous cognition, no 'lattice pegs' from which to hang it.

The platypus stands thus as a particularly apt metaphor for the puzzles of representation leading to definition so beloved of Kant, Peirce and other European philosophers, semioticians and theorists. The Europeans had no insight into the flora and fauna of Australia; it was an alien land for which they had no other perspective than that which they brought with them. They set about re-constructing the land into a 'new Britannia'. In terms of textuality, they conferred an authoritative reading upon it.

What, then, is it for Eco to embrace Kant and the platypus in both his academic and his fictional writings? As he says: 'Kant knew nothing about the platypus, and that should not worry us, but if the platypus is to solve its own identity crisis, it ought to know something about Kant' (Eco 1997: 7). In what ways is the text of the platypus less authoritative, less inscribed, than Kant's writings? Are First Nation ways of knowing before European invasion less because they knew nothing of the philosophical puzzles that Kant studied?

In considering the problem of being, Eco sees words as both defining everything and lying about everything; as leading both to tragedy and comedy, but always through a distortion. At the same time, he sees the academic and the everyday as closer together than some intellectuals might feel comfortable with: '[I]n order to understand how common sense works, there is nothing better than imagining 'stories' in which people behave according to its dictates. In this way we discover that normality is narratively surprising' (Eco 1997: 67). Eco does not see this as displaying a yearning to be a fictional writer for, 'when I feel the urge to tell stories, I satisfy it elsewhere' (Eco 1997: 5). It can thus be said that Eco sees the intellectual and critical judgment as being both 
personal and cultural as well as academic, yet at the same time confined by genre itself.

For Eco, the reader is indeed the writer; the reader enframes meaning and constructs possible worlds. Nowhere is this more explicated than in his bestselling novel The Name of the Rose (1980). As with all writing, the title bears close scrutiny. In itself it proposes that the rose is not, as Gertrude Stein said, 'A rose is a rose is a rose'; nor as William Shakespeare said: 'A rose by any other name would be a rose'. Rather, a rose is a name for a living floral bush that has been captured by the word. The word itself is extremely powerful: 'In the beginning was the Word and the Word was with God and the Word was God' (The Bible quoted in Eco 1983: 399). In Eco's novel, even the power of the Inquisition cannot overtake the power of the word. Even the burning of the mysterious and multi-layered library cannot solve the complex contradiction between past learning, current research, cultural impositions of meaning and the transmission of what is acceptable knowledge.

These are deep philosophical and psychological questions displayed through 'creative writing' in the novel (and film), The Name of the Rose. Eco continued to write such 'fiction' in Foucault's Pendulum (1988) and The Island of the Day Before (1995). Both display his engagement with questions of textuality and discourse leading to meaning. Both are involved in revealing the puzzle of time and space, of power and life, of meaning and the urge to unlock such secrets.

Roberto della Griva, the protagonist in Eco's novel The Island of the Day Before, seems alone on wild seas in a ship that may have command over him, but that he certainly does not command. Again, it is a powerful image of the lives we lead, of how we yearn to construct meaning in meaningless situations and as we too try to understand the secrets of time and the meaning of our journey through life:

Roberto ... does not tell in complete detail what has happened to him, but instead tries to construct his letter like a story, or, more like a sketch for what could become both letter and story, and he writes without deciding what things he will select later; he drafts, so to speak, the pieces of his chessboard without immediately establishing which move to make and how to deploy them. (Eco 1996: 17)

In a comparable vein, Eco's novel The Mysterious Flame of Queen Loana (2004) is about an antiquarian book dealer who can remember nothing about himself, only what he has read. The protagonist, Giambattista Boldoni, sets about re-creating his past by entering the world of popular culture that formed him. It includes Mickey Mouse, Flash Gordon, Sherlock Holmes, the fascist popular culture under Mussolini and the incoming American culture with its Yankee Doodle Dandy. This book positions popular culture and mass media as a significant academic interest of Umberto Eco. It includes insights into the new electronic media as displayed in The Future of the Book (Nunberg 1996). It tries to connect electronic delivery through the reference to Gutenberg to the printed word that in 1996 still dominated the World Wide Web. In seeing the future of the WWW as another triumph for Gutenberg, Eco was entirely mistaken about the multimedia applications that are everywhere apparent in 2007. Multimedia applications have overtaken prose and print, particularly in the use of the mobile phone as well as the conventional computer.

Eco sees Kant as: '...not interested in knowledge of but knowledge that; in other words, interested not in the conditions of knowledge (and therefore of naming) of objects as much as in the possibility of founding the truth of our 
propositions about objects' (author's emphases, Eco 1997: 69). If Kant has no knowledge of a platypus, is it possible for him to have knowledge about it? Is being/existence thus a precondition for knowing? Some millions of Indigenous Australians had knowledge of the platypus for up to 60,000 years: does that validate its existence?

\section{Literature and/as ideology: there is no innocent 'mystory'}

For Eco, semiotic studies are an extension of Kantian sensibilities. Rather than semiotic analyses, an unveiling of ideologies is a basic aim of postmodernist theories that are about writing. This is a difficult task. Terry Eagleton, the Marxist literary theorist, warns us that we are so immersed in our cultural ideologies that they are difficult to identify much less critique or move outside of in our thinking and writing. Literature has played an important part in our acting authoritatively. As such, it provides a fruitful basis for interrogating cultural givens that underpin a canonical view of the role of the creative writer and creative writing itself.

As the twentieth century progressed, especially in England, literature in a canonical sense played an important role in civilizing the underclasses through mass education and the 'natives' of the Empire through mission schools. Eagleton says of this:

Literature would rehearse the masses in the habits of pluralistic thought and feeling, persuading them to acknowledge that more than one viewpoint than theirs existed - namely, that of their masters. It would communicate to them the moral riches of bourgeois civilization, impress upon them a reverence for middle-class achievements, and, since reading is an essentially solitary, contemplative activity, curb in them any disruptive tendency to political action. It would give them a pride in their national language and literature: if scanty education and extensive hours of labour prevented them personally from producing a literary masterpiece, they could take pleasure in the though that others of their own kind - English people - had done so. (Eagleton 1989: 25)

Creative writing, then, was about exploring new ideas presented by others who appeared to be more sophisticated, educated and intellectual. It was not about what we have come to know as the Barthesean ideal of 'readerly-writing', or about postmodernist ideas such as Derrida's 'deconstruction', 'différance', or of textuality and discourse that is 'under erasure'. Since the end of World War 2 in the 1940 s, these have opened up textuality and discourse in a way that many opponents see as destructive, subject to relativity, or reductionist. In a postpost-modernist world, we can readily utilize literature as a space in which the individual reader brings the inert text to life and enters into a personal and non authoritative discourse. Within this discourse literature can be seen to be articulating fantasies in order to extend our understandings of human motivations by investigating areas of the human psyche that are unacceptable to normal social interactions. Through the created works, we understand the place of fantasising in our personal and social lives. Through developing insights into characterization, we enter as readerly-writers into the minds and volitions of characters and explore lives that are different from our own. In this way we live multiple lives. 
Creative writing is dangerous because it should be: it should encourage us to challenge our given social 'received notions' by meeting them within a framework of 'fictional truth'. In this way we are in a non-threatening environment that also enables us to explore a range of ethnic groups and cultures and to investigate a range of social activities that transcend class and culture. In readerly-writing, we may pick up the text or put it down; we are enabled to challenge metanarratives that engulf our culture by meeting challenges to our 'given' social 'received notions'. In a sophisticated world of multiple mediated experiences of 'virtual reality', we may, as readerly-writers, meet and decipher 'virtual reality' in our own terms and with our own understandings as we are transported into a discourse that encourages an interpretation of the many-layered levels of the storyline that has come from the insights and sensibilities of another.

When Barthes declared that the author was dead, he meant that the emphasis on the interchange of ideas in writing had moved from the author - the authoritative voice - to the reader. He saw a text as

not a line of words releasing a single 'theological' meaning (the message of the Author-god) but a multi-dimensional space in which a variety of writing, none of them original, blend and clash. The text is a tissue of quotations drawn from innumerable centers of culture. (Barthes 1977: 142-3)

Thus a new idea was born that the reader is not an inert receiver of authoritative discourse, but is a significant contributor to the understanding of the text. This idea became known as 'the readerly-writer'. Without the author, of course, there is no text. However, there is no discourse without a reader. It is the reader who brings the book to life.

Building upon this idea, Jacques Derrida introduced us to the challenge that everything we read/write is 'under erasure'. By this he means that no text is definitive and eternal; that everything can be replaced by later texts and/or by what the reader(s) make of this text.

As a parallel/metaphor Derrida $(1983,1989)$, deconstructing the discourse of the text of a book provides us with a model for deconstructing the discourse of the text of ourselves and our society: and to write a 'mystory'. Through deconstructing a text we learn much about the text itself and how it has been formed and informed as well as how it intends itself to operate.

\section{Conclusion: does the 'mystory' ever reach one?}

Such postmodernist ideas about writing and reading, textuality and discourse have affected how we think about creative writing. They also show that people who write fictional narratives are in a very powerful position. They produce Kristeva's startling definition of such writing as: 'imaginary constructions phantasmatic, daring, violent, critical, demanding, shy' (my italics, Kristeva 1987: 381). In this way, they move beyond the confines of the authorial into the imaginary construction of the reader. They are neither authoritative nor readerly; they are both.

An imaginary construction may well depend upon a cultural ideology and/or construction, but at the same time it provides the space for moving outside the given metanarratives from which it arises and traces of which may be seen within its textuality and discourse. It can be phantasmatic, moving into the underworld of the unconscious self, into the world of fantasy constructed to 
give meaning to what might otherwise be unattainable to the ego. It can be daring because it is not constrained by the boundaries of conventions. It can be violent because the harm that is surveyed is not physical. Rather, like Frankenstein, the possible monster within becomes a fictional monster outside who can be vilified by self instead of consuming of self. Whereas non-fictional writing can be constrained by all sorts of pressures including legal responsibilities/threats, fictional narratives provide a space for critical commentary upon/outside the cultural discourse as well as within it. Fictional narrative is demanding because it takes the writer and reader outside the comfort zone and challenges perception and preconceptions, thus offering different prisms through which to view and understand that which was thought to be known. It can be shy because it can hide as it reveals, it can be 'under erasure' so that it is not truth-seeking per se.

Yet surely, in a very real sense, all writing is created fictional narrative? All writing is 'phantasmatic, daring, violent, critical, demanding and shy'. This mystory, then - the one I have written here, the one you are reading - acts in a way that shows its construction:

....unlike the treatise, or the conventional genres of academic scholarship, the mystory does not repeat, is not reproduced, in that no two are alike. ... Mystory itself is more a relay than a model, produced not for its own sake, but as the trace of convergence of living and artificial memories. (Ulmer 1989: 171)

\section{References}

Arnold, J 1994 Postmodernism, feminism and education: a textual performance, Unpublished $\mathrm{PhD}$ thesis, Deakin University, Geelong return to text

Barthes, R 1977 Image-Music-Text, London: Fontana Collins return to text

Cherryholmes, C 1988 'Construct validity and the discourses of research', American Journal of Education, 96.3, 421-457 return to text

Derrida, J 1983 Writing and Différance, London: Routledge and Kegan Paul return to text

Derrida, J 1989 'Some statements and truisms about neologisms, newisms, postisms, parasitisms, and other small seismisms', D Carroll (ed.), The States of Theory (pp. 63-94), New York:

Columbia University Press return to text

Eagleton, T 1989 Literary Theory: An introduction, Manchester: Manchester University Press return to text

Eco, U 1983 The Name of the Rose, San Diego: Harcourt Brace and Jovanovich return to text

Eco, U 1996 The Island of the Day Before, London: Mandarin Paperbacks return to text

Eco, U 1997 Kant and the Platypus: Essays on language and cognition (translated by Alistair McEwen), Orlando: Harcourt return to text

Eco, U 2005 The Mysterious Flame of Queen Loana (translated by Geoffrey Block), Orlando: Harcourt return to text

Kristeva, J 1987 Tales of Love, Columbia: Columbia University Press return to text 
Lyotard, J 1988 Pereginations: Law, form, event, New York: Columbia University Press return to text

May, T 2006 Gilles Deleuze: An introduction, Cambridge: Cambridge University Press return to text

Midgley, M 2006 The Myths We Live By, London: Routledge return to text

Nunberg, G (ed) 1996 The Future of the Book, Berkeley: University of California Press return to text

Sonesson, G 1988 Methods and Models in pictorial semiotics: Report 3 from the Project 'Pictorial meanings in the society of information' [Electronic Version], at http://www.arthist.lu.se/kultsem/pdf/rapport3.pdf (accessed 20 October 2005) return to text

Spender, D (ed) 1991 Heroines: A contemporary anthology of Australian women writers, Melbourne: Penguin return to text

Spivak, G 1988 In Other Worlds: Essays in cultural politics, London: Routledge return to text

Stanbury, P, \& Phipps, G 1980 Australia's Animals Discovered, Sydney: Pergamon Press

Sutherland, J 2006 'Julia Kristeva: Travelling through fact and fiction', The Age, 25 March, 13 return to text

Ulmer, G 1989 Teletheory: Grammatology in the age of video, NY: Routledge return to text

Ulmer, G \& Memmott, T 2000 'Toward Electracy: a conversation with Gregory Ulmer' [Electronic Version], BeeHive Archive 3. 4 (December) at http://beehive.temporalimage.com/archive/34arc.html (accessed 18 March 2007) return to text

Dr Josie Arnold is the inaugural Professor of Writing at Swinburne University of Technology. She has taught for 45 years and has had over 40 books published in a number of genres. Since 2002 she has established an online Master of Arts (Writing) course and a Practice Led Research PhD following an artefact and exegesis model. She is currently writing a series of magic gamesbased books for pre-teenagers. Her research is currently focussed upon the practical implications of critical and cultural theories and the impact of the cyber upon writing.

TEXT

Vol 11 No 2 October 2007

http://www.textjournal.com.au

Editors: Nigel Krauth \& Jen Webb

Text@griffith.edu.au 